\title{
An updated water balance for the Grootfontein aquifer near Mahikeng
}

\author{
JE Cobbing ${ }^{1 *}$ \\ 'AEON/ESSRI: Africa Earth Observatory Network / Earth Stewardship Science Research Institute, Faculty of Science, Nelson Mandela University, \\ Summerstrand, Port Elizabeth, 6031, South Africa
}

\begin{abstract}
The Grootfontein Aquifer, part of the important North West dolomite aquifers, supplies about 20\% of Mahikeng's domestic water needs. Over-abstraction caused the large natural spring draining the aquifer to disappear in 1981, and groundwater levels have since fallen nearly $30 \mathrm{~m}$ in the vicinity of the former spring. Analysis of water levels and a water balance using recent assessments of groundwater abstractions confirm past work describing the hydrogeological functioning of the aquifer, and suggest that current abstractions need to fall by between 19 and $36 \mathrm{ML} /$ day $\left(7\right.$ and $\left.13 \mathrm{Mm}^{3} / \mathrm{a}\right)$ to bring the aquifer back into longterm balance. Continued over-abstraction at Grootfontein implies increasing risk to Mahikeng's water supply, and illuminates the larger challenge of ensuring groundwater use in the North West dolomites that is sustainable and in the public interest.
\end{abstract}

Keywords: Groundwater, North West dolomites, Mahikeng, over-abstraction, irrigation

\section{INTRODUCTION}

The Grootfontein aquifer is of particular interest because it is well studied hydrogeologically, and it is part of the domestic water supply of Mahikeng, the capital of North West Province. The decades of hydrogeological studies at Grootfontein contrast with its poor management, evidenced by falling groundwater levels (see below). The management of the aquifer is the collective outcome of a diverse and complex series of interacting issues, rather than being primarily a question of hydrogeological data. However, the hydrogeology provides a fundamental basis or 'envelope of possibility' for management, and its description is necessary and important.

South Africa's dolomite aquifers are amongst the highestyielding and most important aquifers in the country (Barnard, 2000). The dolomites of North West Province (Fig. 1), known as the North West dolomites, hold around $5000 \mathrm{Mm}^{3}$ of water (about the same as the Gariep Dam), and are recharged at a rate of about $300 \mathrm{Mm}^{3} / \mathrm{a}$ (Stephens and Bredenkamp, 2002). The North West dolomites are divided into a number of discrete units or 'compartments' by igneous dykes and faults (Meyer, 2012), making them a patchwork of semi-autonomous aquifers rather than a single hydraulic entity. Under natural conditions, rainfall recharges these compartments / aquifers, and they drain via springs, seeps and wetlands. Some of the springs draining North West dolomite compartments are large and important - for example, the Molopo Eye near Mahikeng and the Maloney's Eye near Mogale City are the sources of the Molopo and Magalies Rivers, respectively. Both have long-term average flow rates exceeding $30 \mathrm{ML} /$ day or $11 \mathrm{Mm}^{3} / \mathrm{a}$ (DWS NGA data; Vahrmeijer et al., 2013). Over-abstraction in some of the dolomite compartments is a growing problem, threatening domestic supplies, irrigated agriculture and environmental services.

Whilst most dolomite groundwater is used for irrigation, hundreds of thousands of people also depend on it for domestic water supply. It also supports many springs, wetlands

To whom all correspondence should be addressed.

+1 2023617865 ;

e-mail: jcobbing@gmail.com

Received 17 February 2017, accepted in revised form 5 December 2017. and associated ecosystems. Bodibe, Lichtenburg, Itsoseng, Ventersdorp, Mahikeng, Ottoshoop and Zeerust, amongst other towns, all rely mainly on dolomite groundwater for municipal water supplies.

Mahikeng is one of the largest and most important groundwater-dependent towns in South Africa. Mahikeng's water demand is about $50 \mathrm{ML} /$ day $\left(18.3 \mathrm{Mm}^{3} / \mathrm{a}\right)$. About $20 \mathrm{ML} /$ day $\left(7.3 \mathrm{Mm}^{3} / \mathrm{a}\right)$ of this water comes from the Setumo Dam, on the Molopo River to the west of Mahikeng. Groundwater from the Molopo Eye spring and from boreholes in the Grootfontein aquifer supply the other $30 \mathrm{ML} /$ day $\left(11 \mathrm{Mm}^{3} / \mathrm{a}\right)$ - roughly $20 \mathrm{ML} /$ day $\left(7.3 \mathrm{Mm}^{3} / \mathrm{a}\right)$ from the spring and $10 \mathrm{ML} /$ day $\left(3.7 \mathrm{~m}^{3} / \mathrm{a}\right)$ from the boreholes. Both the Molopo Eye spring and the Grootfontein aquifer are located in the North West dolomites, about $30 \mathrm{~km}$ east of Mahikeng. The Setumo Dam depends on intermittent flows from the Molopo River (which originates at the Molopo Eye), and on leaks and effluent return flows from Mahikeng. The dam is therefore partly dependent on North West dolomite groundwater too.

Before the early 1980s the Grootfontein aquifer used to discharge naturally at a large spring, the Grootfontein Eye. This spring used to be the primary water source of Mahikeng (and nearby Mmabatho). Municipal officials drilled boreholes around the Grootfontein Eye in the 1970s to augment the municipal water supply. Irrigation from the Grootfontein aquifer also grew rapidly, starting in the 1960s. These combined groundwater abstractions led to the spring disappearing in October 1981, after which groundwater levels in the Grootfontein aquifer fell. Today the water table in the vicinity of the old Grootfontein Eye is more than $28 \mathrm{~m}$ below ground level. This fall in groundwater level has led to some of the municipal boreholes failing, and it now also threatens some of the irrigation boreholes. The volume of water that the remaining Grootfontein boreholes yield to Mahikeng has fallen by more than $60 \%$ over the past 10 years to today's approximately $10 \mathrm{ML} /$ day (3.7 Mm³/a) (DWS, 2014). Overabstraction in the Grootfontein aquifer continues today, and it is likely that domestic supply abstractions will decline further. To compensate, Mahikeng increasingly relies on flows from the Molopo Eye spring (located in a different dolomite compartment to the north of Grootfontein), and on the 


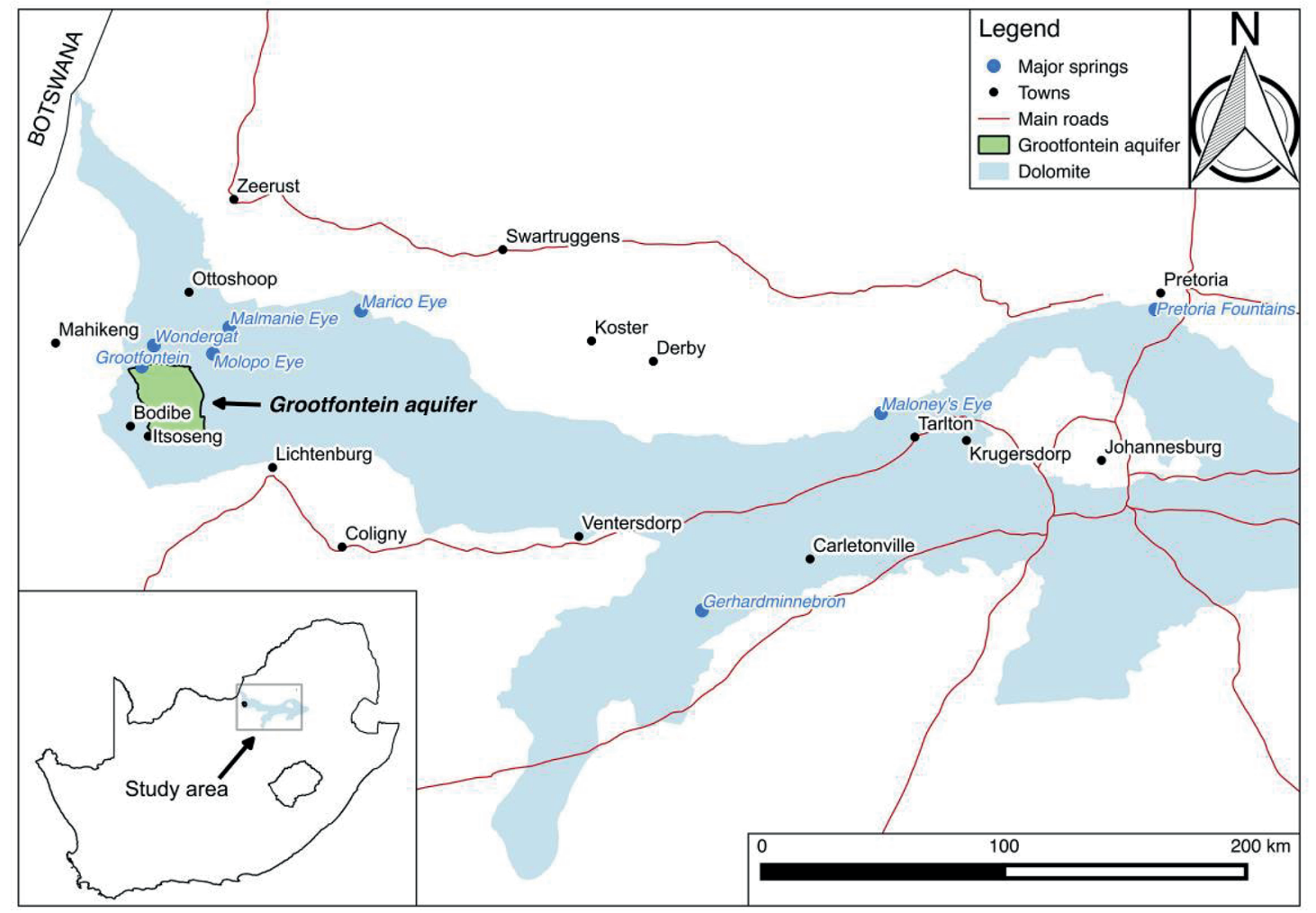

Figure 1

Regional overview (boundaries after Holland and Wiegmans, 2009)

\begin{tabular}{|c|c|}
\hline \multicolumn{2}{|r|}{$\begin{array}{c}\text { TABLE } 1 \\
\text { Hydrogeological data used }\end{array}$} \\
\hline Data type & Source and description \\
\hline Groundwater levels & $\begin{array}{l}\text { DWS National Groundwater Archive (NGA) data for } 34 \text { water-level measuring stations in and } \\
\text { around the Grootfontein aquifer. Confirmed by dipmeter measurements in the vicinity of the } \\
\text { former eye. }\end{array}$ \\
\hline $\begin{array}{l}\text { Former Grootfontein Eye } \\
\text { flows }\end{array}$ & $\begin{array}{l}\text { Literature review, personal communications. The Grootfontein Eye has not flowed since 1981, } \\
\text { and no single continuous record of its former flow was obtained. }\end{array}$ \\
\hline $\begin{array}{l}\text { Public water supply borehole } \\
\text { pumping rates }\end{array}$ & Literature review, personal communications, DWS pumping data obtained for 2015. \\
\hline $\begin{array}{l}\text { Irrigation borehole pumping } \\
\text { rates }\end{array}$ & $\begin{array}{l}\text { Literature review, personal communications, estimates derived by private consultants obtained } \\
\text { for use in WRC Project K5/2429 (Eales, 2015). }\end{array}$ \\
\hline WARMS license data & $\begin{array}{l}\text { DWS WARMS database representing licensed amounts at Grootfontein. Actual use may be } \\
\text { higher or lower. }\end{array}$ \\
\hline $\begin{array}{l}\text { Major and minor ion } \\
\text { chemistry }\end{array}$ & $\begin{array}{l}\text { Sixteen samples were collected in and around Grootfontein in 2015, and analysed for major } \\
\text { elements and minor (trace) ion content. See Table } 3 .\end{array}$ \\
\hline Aquifer properties data & $\begin{array}{l}\text { Literature survey, particularly the DWS GH series of reports. Dyke boundaries were estimated } \\
\text { by Holland and Wiegmans (2009), based on literature review, geophysical data and analysis of } \\
\text { water levels. }\end{array}$ \\
\hline Aerial photographs & $\begin{array}{l}\text { Chief Directorate National GeoSpatial Planning, part of the Department of Rural Development } \\
\text { and Land Reform. }\end{array}$ \\
\hline $\begin{array}{l}\text { Field observations and } \\
\text { interviews }\end{array}$ & Observations made during field visits in 2013, 2014 and 2015. \\
\hline
\end{tabular}


upgraded water treatment plant at the Setumo Dam. Municipal officials are concerned about the decline in yield from the Grootfontein boreholes since the city then depends more on the remaining sources, and is less resilient during drought. The water from the Setumo Dam is also polluted, and consequently expensive to treat (DWS, 2014). Finally, the dewatered state of the Grootfontein aquifer means that it cannot be used as a backup supply during a prolonged drought, a temporary breakdown at the Setumo Dam, or another crisis.

\section{METHOD AND RATIONALE}

Here I use existing and new data for an updated hydrogeological description of the Grootfontein aquifer, in order to anchor and substantiate future discussion of the management of the Grootfontein aquifer, as well as the management of North West dolomite groundwater in the public interest, more generally. The hydrogeological description advanced here largely accords with past descriptions of the aquifer's functioning and confirms the need for better management of abstractions. Discussions of management options at Grootfontein are still dominated by aspects of hydrogeological functioning, and hydrogeological uncertainty is advanced as a reason for management inaction. There is a pressing need to consolidate contemporary hydrogeological knowledge at Grootfontein, including modern water level measurements, to demonstrate that current hydrogeological understanding is sufficient to support better management.

Field data collection, including interviews and meetings with stakeholders, was conducted between 2013 and 2015 . Existing and new hydrogeological data for the Grootfontein aquifer used in this analysis is shown in Table 1.
These data were analysed and combined with a literature review to produce the updated conceptual hydrogeological description of the Grootfontein aquifer. The results of the work are described in two sections: an updated conceptual hydrogeological description, and a water balance. These two sections are presented below. The first 'results' section is further divided into sub-sections reflecting the various aspects of hydrogeological functioning.

\section{RESULTS: CONCEPTUAL DESCRIPTION OF THE GROOTFONTEIN AQUIFER}

\section{Topography and geology}

The Grootfontein aquifer or compartment covers an area of approximately $239 \mathrm{~km}^{2}$, based on the boundaries of Holland and Wiegmans (2009). The flat, weathered land surface slopes very gently towards the north, with a gradient of approximately $50 \mathrm{~m}$ in $16 \mathrm{~km}$. Average annual rainfall is about $560 \mathrm{~mm}$, falling mainly as summer thunderstorms. The Grootfontein aquifer falls within quaternary drainage region D41A. The course of the Droë Molopo River cuts across the far north-east corner of the aquifer, and former marshland (now dry) associated with this water course indicates that groundwater would once have contributed to the Droë Molopo, along with the flow from the Grootfontein Eye (Fig. 2). Both the Droë Molopo and the unnamed drainage from the Grootfontein Eye join the Molopo River about $6 \mathrm{~km}$ due north of the Grootfontein aquifer boundary. A further area of marshy ground existed at Blaauwbank near the centre of the aquifer. No marshy ground occurs today due to the drop in the water table.

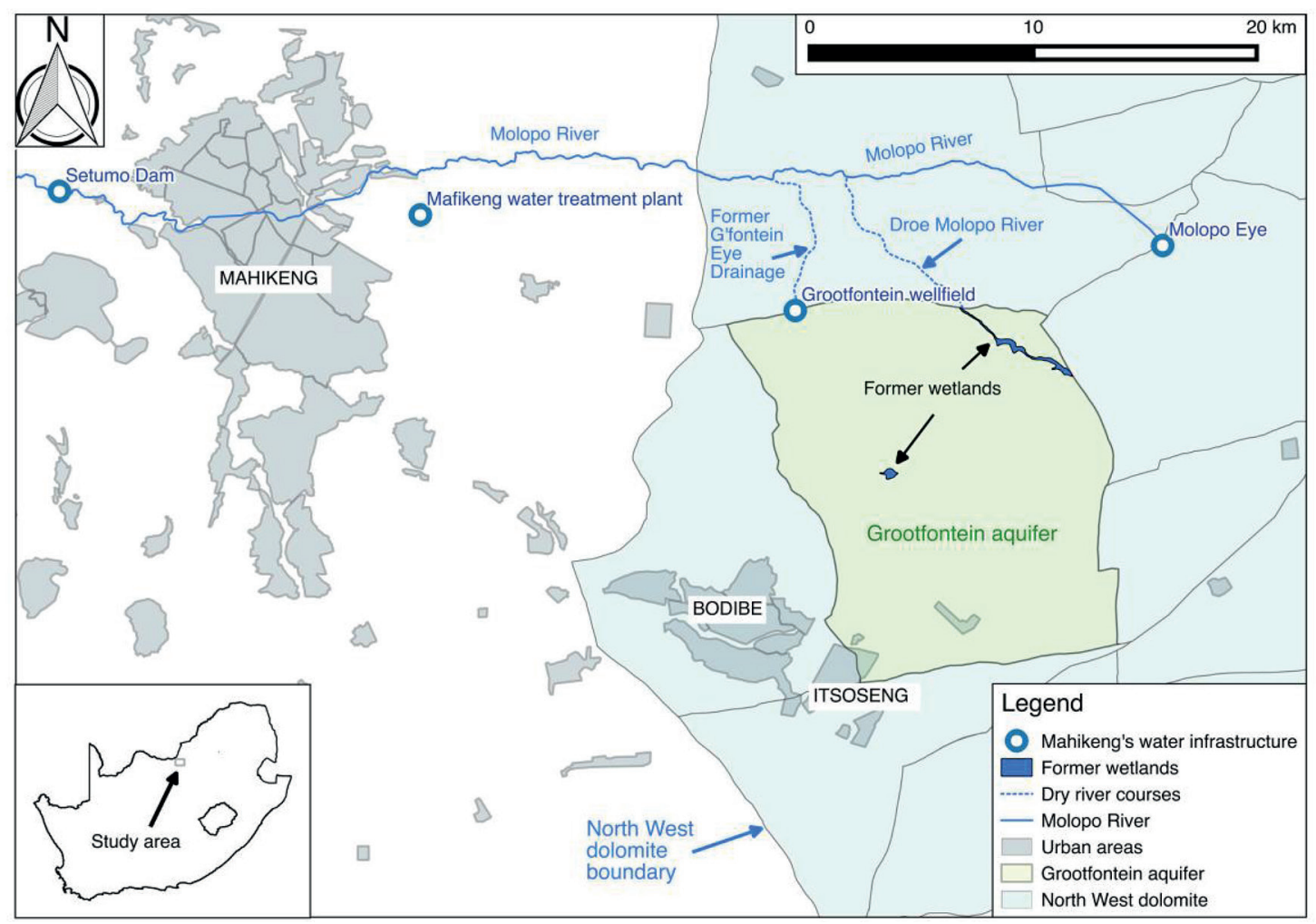

Figure 2

The Grootfontein aquifer and surrounds (compartment boundaries after Holland and Wiegmans, 2009) 
Formed around 2.7 billion years ago, dolomites of the Chuniespoort Group (Transvaal Supergroup) have been tectonically deformed and faulted, and are intruded by igneous dykes (Tinker et al., 2002). The dolomite outcrops as a moderately hard, grayish- to brown-coloured rock, often weathering to a surface 'elephant skin' texture.

The Malmani Subgroup of the Chuniespoort Group is the main water-bearing unit, and is divided into formations based partly on chert content (Table 2). In the Grootfontein area these formations are the Eccles, Lyttelton, Monte Christo and Oaktree Formations (Johnson et al., 2006). The Eccles and Monte Christo Formations are chert-rich, whilst the Lyttelton Formation is chert free. The chert-rich Eccles and Monte Christo formations are more susceptible to weathering, and the resulting voids are supported by the more resistant chert. As a result, coefficients of storativity and transmissivity are higher, and they are better aquifers (Holland and Wiegmans, 2009; Meyer, 2012). The Monte Christo Formation has been further sub-divided into 3 sub-formations or members. The entire sequence dips to the north beneath the Pretoria Group.

The area of the Grootfontein compartment is partly covered by Quaternary alluvium and soils with good agricultural potential (Stephens and Bredenkamp, 2002). This contrasts with areas of poor agricultural potential with thin or absent soil cover, known as 'klipveld' (Bredenkamp, 1964).

\section{Compartment boundaries}

Vertical to sub-vertical diabase dykes oriented mainly E-W intrude the country rocks of the study area. These dykes vary in thickness from a few metres to tens of metres and show different weathering profiles. Those dykes that are deeply weathered do not affect groundwater flow appreciably (Cogho, 1982). The dykes vary in age, with the oldest dykes in the study area associated with the Bushveld Complex ( $\pm 2 \mathrm{Ga}$ ) and the youngest $(182 \mathrm{Ma}$ ) related to the Karoo Igneous Province (Tinker et al., 2002). A radiometric (Ar-Ar) date obtained by Day (1981) for a sample of dyke material near to the Molopo Eye was $1262 \pm 8 \mathrm{Ma}$. Dyke exposure in the Grootfontein area is poor, and in general they cannot be identified visually in the field. Aerial photography, magnetic surveys and drilling are used to identify and map dykes.

The Grootfontein aquifer is bounded or compartmentalised by sub-vertical diabase dykes of varying thicknesses and hydraulic properties (Holland and Wiegmans, 2009). A detailed study of the geology of the dykes in the area was carried out by Day (1981) who used aerial photography and aeromagnetic data, confirmed by ground magnetic data, to produce a magnetic and photo-lineament map of the area. Day's work did not establish hydraulic properties for the dykes, however, beyond saying that they are of considerable hydraulic importance (Day, 1981:19). Subsequent studies have estimated aquifer compartment boundaries using dyke thicknesses, pumping tests and changes in groundwater levels (Holland and Wiegmans, 2009).

Figure 3 below shows the Grootfontein aquifer with the compartment boundaries as mapped by Holland and Wiegmans (2009). The geology, lineaments and dykes are derived from the 1:250 000 scale geological mapping of the Council for Geoscience (CGS, 1981; 1986; 1991; and 1993) and the dyke names are after Day (1981).

TABLE 2

Stratigraphic column (not to scale) showing major lithologies in the Grootfontein area (after Barnard, 2000; CGS, 1991; Johnson et al., 2006; Meyer, 2012)

\begin{tabular}{|c|c|c|c|c|c|}
\hline $\begin{array}{l}\text { Appx. Age } \\
\text { (Ma) }\end{array}$ & Supergroup / Period & Group & \multicolumn{2}{|l|}{ Formation } & Lithology \\
\hline $0-2.6$ & $\begin{array}{l}\text { Quaternary / } \\
\text { Tertiary }\end{array}$ & Kalahari & \multicolumn{2}{|l|}{ Gordonia } & Sands, gravels, alluvium, calcrete \\
\hline \multirow{3}{*}{$65-570$} & \multirow{3}{*}{ Karoo Supergroup } & Intrusives & \multicolumn{2}{|c|}{ Karoo dolerite } & Intrusive dolerite dykes, sills \\
\hline & & Ecca & \multicolumn{2}{|c|}{ Volksrust, Vryheid } & Mudstones, shales, sandstones \\
\hline & & \multicolumn{3}{|l|}{ Dwyka } & Tillite, shale, mudstone, sandstone \\
\hline \multirow{8}{*}{$2050-2700$} & \multirow{8}{*}{$\begin{array}{l}\text { Transvaal } \\
\text { Supergroup }\end{array}$} & Pretoria & \multicolumn{2}{|c|}{$\begin{array}{l}\text { Magaliesberg, Daspoort, } \\
\text { Hekpoort, Timeball Hill }\end{array}$} & Quartzite, shale, andesite \\
\hline & & \multirow{7}{*}{ Chuniespoort } & \multicolumn{2}{|l|}{ Penge } & Dolomite, chert \\
\hline & & & \multirow{5}{*}{$\begin{array}{l}\text { Malmani } \\
\text { Subgroup }\end{array}$} & Frisco & $\begin{array}{l}\text { Stromatolitic dolomite, chert-poor } \\
\text { dolomite, shale }\end{array}$ \\
\hline & & & & Eccles & Interbanded dolomite and chert \\
\hline & & & & Lyttleton & Chert-poor dolomite, shale, quartzite \\
\hline & & & & $\begin{array}{l}\text { Monte } \\
\text { Christo }\end{array}$ & $\begin{array}{l}\text { M1 - Chert-rich dolomite } \\
\text { M2 - Interbanded chert \& dolomite } \\
\text { M3 - Oolitic chert \& dolomite }\end{array}$ \\
\hline & & & & Oaktree & Chert-poor dolomite, carbonaceous shale \\
\hline & & & \multicolumn{2}{|l|}{ Black Reef } & Quartzite, conglomerate \\
\hline $2700-2800$ & $\begin{array}{l}\text { Ventersdorp } \\
\text { Supergroup }\end{array}$ & \multicolumn{4}{|c|}{ Andesite, quartz porphyry, conglomerate, calcareous shale, quartzite, lava } \\
\hline $3090+$ & Basement Complex & \multicolumn{4}{|l|}{ Granite, gneiss } \\
\hline
\end{tabular}


Most authors agree that the northern boundary of the Grootfontein aquifer is the Grootfontein and Trekdrift Dykes. The Grootfontein Dyke is more than $20 \mathrm{~m}$ thick and is semipermeable, with a step change in water level across it of about $6 \mathrm{~m}$ reported by Van Tonder et al. (1986). The Trekdrift Dyke is narrower and also shows water level changes across it. The point where the two dykes meet is an anomalous depression in the dolomite, interpreted as a fossil sinkhole now filled with low-permeability clay-rich Karoo sedimentary rocks (Van Tonder et al., 1986). The low permeability Mooimeisjesfontein Dyke forms the western boundary of the aquifer, and shows water level changes across it of about $1 \mathrm{~m}$ (Van Tonder et al., 1986). The eastern boundary of the aquifer is the Elizabeth Dyke, which also has a low permeability and a water level change of about $2 \mathrm{~m}$ (with the higher level on the eastern side) (Van Tonder et al., 1986). In the south this dyke is known as the Elizabeth II Dyke (Day, 1981). The southern boundaries of the aquifer are more controversial. Van Tonder et al. (1986) report that one of at least three dykes may form this boundary (the Blaauwbank, Grasfontein and Stryd Dykes), or some combination of the three. In 1986 the Blaauwbank Dyke showed water levels on its southern side about $12 \mathrm{~m}$ higher than those on its northern side. Testing of boreholes in this 80 $m$ wide dyke indicate an extremely low permeability, and it is thought that little water flows from south to north across it (van Tonder et al., 1986).

Following their study of water levels, Holland and Wiegmans (2009) placed the southern boundary of the Grootfontein aquifer farther south, extending to the Paarl Dyke, running east-west immediately to the south of the Itsoseng boreholes. Today this dyke is most commonly considered to define the southern boundary of the aquifer.
Groundwater contours, which reveal flow from the southeast towards the north-west, provide some evidence for groundwater flow across the south-eastern boundary of the Grootfontein aquifer. The Verlies Dyke and other un-named dykes and lineaments cut across the aquifer from south-west to north-east (Day, 1981; Cogho and Bredenkamp, 1982) but these are not thought to disrupt groundwater flow substantially (Holland and Wiegmans, 2009).

\section{Aquifer physical properties}

Whilst the primary porosity and hydraulic conductivity of dolomite rock is poor, weathering and karstification in the North West dolomites makes them prolific aquifers where the thickness of the deposits and the depth of weathering allow. Weathering is limited by overburden, and at depth aquifer characteristics are generally poor.

The Grootfontein aquifer thickness is a function of weathering and karstification, and is thought to vary from about $40 \mathrm{~m}$ in the north-west to about $60 \mathrm{~m}$ in the south-east of the aquifer (Van Tonder et al., 1986; Cogho, 1982). Transmissivity (T) value distribution is a function of the extreme heterogeneity of the weathered dolomite, with pumping tests showing $\mathrm{T}$ values of up to $23000 \mathrm{~m}^{2} / \mathrm{d}$ for the dolomites and up to $16 \mathrm{~m}^{2} /$ day for the diabase dykes (Van Tonder et al., 1986). The diabase dykes are often presumed to be impermeable for planning purposes (Janse van Rensburg, 1992).

Specific yield values ranging from $1 \%$ to $18 \%$ are found in the literature (e.g. Enslin, 1967), with most authors quoting values of between $2 \%$ and $4 \%$ (Mulder, 1982; Cogho, 1982; Bredenkamp and Van Rensburg, 1983; Van Tonder et al., 1986; Janse van Rensburg, 1992).

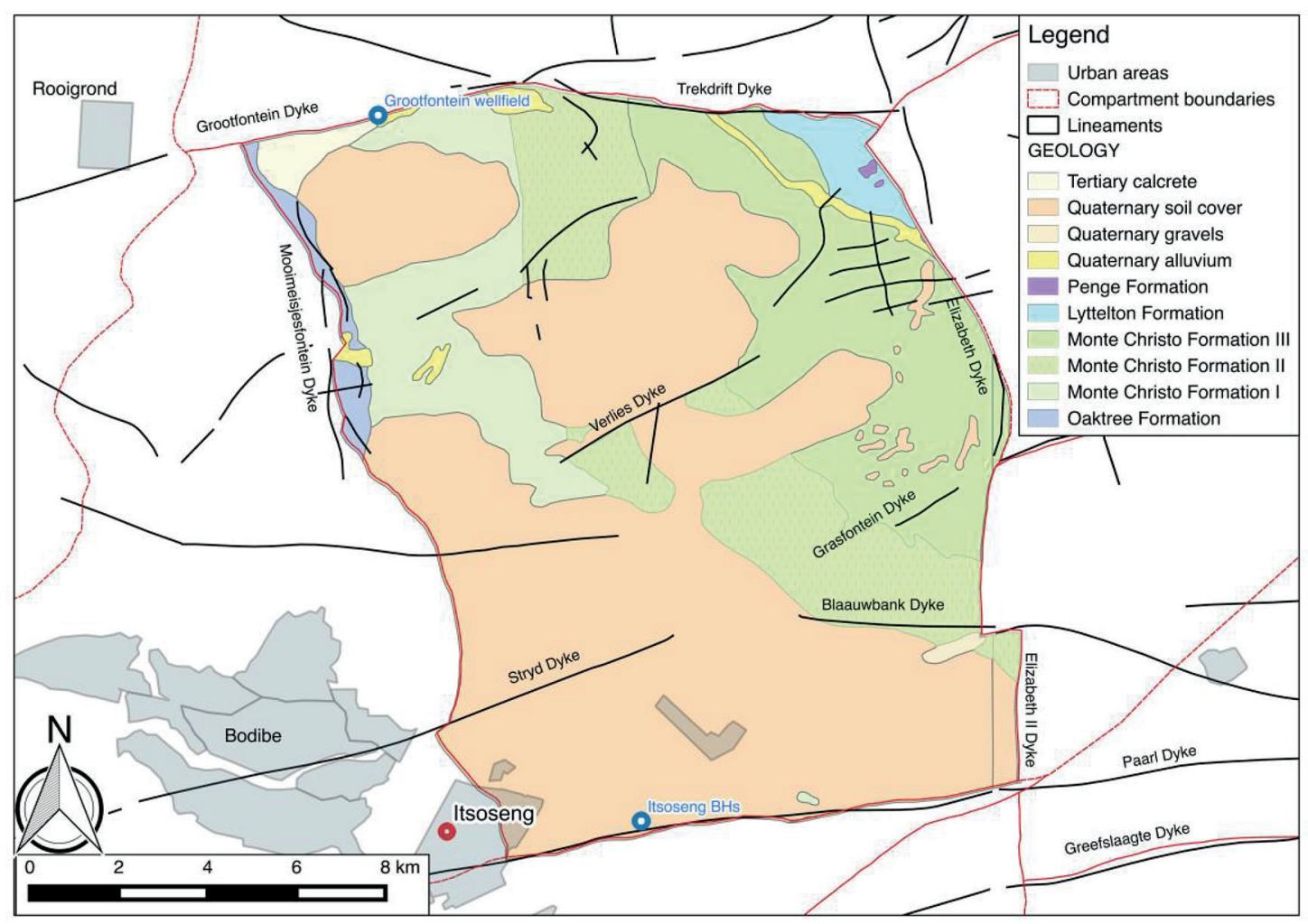

Figure 3 


\section{Groundwater quality}

Groundwater quality in the North West dolomites generally, and in the Grootfontein compartment specifically, is considered good by several authors. For example, Meyer (2014) reports that more than $95 \%$ of analyses on record for the Karst Belt dolomites (i.e. the dolomites stretching from Delmas in the east to the Botswana border in the west) are within the Class 1 electrical conductivity category $(<150 \mathrm{mS} / \mathrm{m})$. Barnard (2000) reports that 223 water samples from the Chuniespoort dolomites falling within the area of the General Series hydrogeology map 2526 (Johannesburg) had a mean $\mathrm{EC}$ of $62.9 \mathrm{mS} / \mathrm{m}$, a mean $\mathrm{pH}$ of 7.6, and a $\mathrm{CaMg}-\mathrm{HCO}_{3}$ water type. DWS (2006) state that 'groundwater quality is reported as being good and mostly in a pristine state' in the North West dolomites, with electrical conductivities of less than $70 \mathrm{mS} / \mathrm{m}$ (DWS, 2006 p 31).

Sixteen water samples were collected in and around the Grootfontein compartment between April and July 2015 (Table 3), at locations where pumping boreholes were available and permission was obtained to sample. The depths of the sampled boreholes were not available.

The samples were collected in $1 \mathrm{~L}$ plastic bottles, which were rinsed with sample and then filled to the brim, capped and sealed with tape. The samples were kept cool and submitted to a SANAS-accredited laboratory for analysis. Samples were analysed for a suite of major ions, $\mathrm{pH}, \mathrm{EC}$ and total alkalinity. An ICP scan for minor constituents was also performed. Sample results were compared with the South African National Standard for drinking water (SANS 241-1:2011; and SANS 2412, 2011). The SANS 241 standards provide physical, aesthetic and chemical numerical limits based on an assumption of lifetime human consumption. The risk of exceeding these limits falls into 4 categories: aesthetic, operational, chronic health and acute health.
The $\mathrm{pH}$ values of the samples are in the expected range for dolomite water, with all samples between 7.3 and 8 (apart from the Setumo Dam sample, which has a high concentration of partially treated wastewater and a $\mathrm{pH}$ of 9.2). Electrical conductivities are $100 \mathrm{mS} / \mathrm{m}$ or below, well within the SANS limit. Sulphate concentrations are less than $10 \mathrm{mg} / \mathrm{L}$ for all except 5 of the samples.

Of the major ion constituents, only nitrate exceeds the guidelines for any of the samples. Samples 3, 7 and 13 all have nitrate ion concentrations greater than $11 \mathrm{mg} / \mathrm{L} \mathrm{NO}_{3}-\mathrm{N}(17$, 17 and $19 \mathrm{mg} / \mathrm{L}$, respectively), implying an acute health risk according to the SANS standards. All of the groundwater samples bar one (Sample 2) show levels of nitrate concentration well above the detection limits of the laboratory analytical equipment. In contrast the Molopo Eye sample (Sample 11), from a neighbouring dolomite compartment with little agricultural activity, has a nitrate concentration of $0.9 \mathrm{mg} / \mathrm{L}$. Concentrations of livestock were observed close to several sampling points, and together with fertilizer applications some level of nitrate contamination is to be expected in Grootfontein groundwater. Two of the three samples with high nitrate concentrations (Samples 3 and 7, both with nitrate concentrations of $17 \mathrm{mg} / \mathrm{L}$ ) also have elevated sulphate concentrations (38 and $34 \mathrm{mg} / \mathrm{L}$ of sulphate, respectively) which, whilst well within the SANS guideline value, also suggests anthropogenic pollution.

Of the minor constituents, arsenic concentrations are above the SANS guideline limit for chronic health risk of $0.01 \mathrm{mg} / \mathrm{L}$ in 6 samples, and selenium levels are similarly elevated in 4 samples. These results may be related to the leaching of inorganic fertilizers into groundwater (MDH, 1999).

The samples have a CaMg- $\mathrm{HCO}_{3}$ signature and cluster closely together when plotted as a Piper diagram, apart from the Setumo Dam sample (Sample 5). This suggests relatively homogeneous groundwater and an undifferentiated and

\begin{tabular}{|l|l|c|c|}
\hline \multicolumn{4}{|c|}{ TABLE 3 } \\
\hline Sample & Description of sample site & \multicolumn{1}{c|}{ Latitude } & \\
\hline & $\begin{array}{l}\text { Combined outflow of the 3 DWS public water } \\
\text { supply boreholes at Grootfontein }\end{array}$ & -25.917167 & 25.860861 \\
\hline 2 & Domestic water supply borehole & -25.913944 & 25.872389 \\
\hline 3 & Domestic water supply borehole & -25.915361 & 25.868583 \\
\hline 4 & Public water supply borehole & -26.076389 & 25.920667 \\
\hline 5 & Setumo Dam sample near dam wall & -25.856528 & 25.508611 \\
\hline 6 & Irrigation borehole & -26.054528 & 25.954889 \\
\hline 7 & Domestic water supply borehole & -25.915667 & 25.869250 \\
\hline 8 & Irrigation borehole & -25.925611 & 25.863861 \\
\hline 9 & Irrigation borehole & -25.925417 & 25.863833 \\
\hline 10 & Irrigation borehole & -25.934667 & 25.910667 \\
\hline 11 & Molopo Eye taken at eastern end & -25.887528 & 26.026500 \\
\hline 12 & Domestic water supply borehole & -26.097167 & 25.984250 \\
\hline 13 & Irrigation borehole & -26.087361 & 25.973500 \\
\hline 14 & Thusong Hospital borehole & -26.054389 & 25.949389 \\
\hline 15 & Irrigation borehole & -26.035611 & 25.952694 \\
\hline 16 & Domestic water supply borehole & -25.906722 & 25.911583 \\
\hline
\end{tabular}


well-connected aquifer. In general, these water quality results confirm previous studies that point towards a high-quality groundwater resource suitable for domestic supply and needing little treatment, even though anthropogenic impacts have been detected in some samples.

The quality of the Grootfontein groundwater can be contrasted with the poorer raw water quality from the Setumo Dam, which requires flocculation, settling, diffused air flotation and filtration, as well as 'ozonation to deal with excessive total organic carbon (TOC) levels in the water and granulated activated carbon (GAC) filters to deal with taste and odour problems arising from the high algal content of the raw water' (DWS, 2014 p 5).

\section{Water level analysis}

DWS collects groundwater-level information in South Africa as part of its ongoing monitoring programme. This data is entered into the HYDSTRA database, from where a selection is exported to the publicly accessible National Groundwater Archive (NGA). Data obtained in June 2015 from the NGA indicates that North West Province has 129 groundwater level monitoring stations that are currently active. Most of these stations are monitored manually (i.e. using a hand-held dipmeter) and all except two are monitored quarterly. A subset of 34 groundwater-level monitoring stations was identified for the Grootfontein aquifer. Of these 34 stations, 21 are located within the aquifer whilst the other 13 are less than $3 \mathrm{~km}$ outside of its border. All 34 stations are either currently active, or have monitoring records that ended in the past 6 years. All but 3 of these 34 station records began recording in the 14 years between 1972 and 1986, a time of increasing irrigation at Grootfontein. The earliest record is Station D4N0103, which began recording in February 1972. Irrigation is known to have started before the 1960s in the Grootfontein compartment and surrounds (Temperley, 1965), but records showing groundwater levels in the Grootfontein area before the early 1970s are scarce.

A best-fit straight line through the data was added to each record in MS Excel, and the gradients of the lines were compared. An average gradient (or rate of decline in metres per day) of 0.00113 for all 34 records, and of 0.00126 for the 21 records inside the compartment, was calculated. This is equivalent to a fall in water level of $4.1 \mathrm{~m}$ per decade for all records, or $4.6 \mathrm{~m}$ per decade for those records within the compartment boundaries. Individual record gradients within the compartment boundaries vary by an order of magnitude (i.e. 0.0002 for D4N0838 and 0.0023 for D4N0088). This is expected due to the great heterogeneity of a karst aquifer such as Grootfontein, and the local effects of large-scale abstractions.

The DWS water-level records are confirmed by water-level measurements taken in the field for this research in April 2015. The average water level for 3 boreholes within a few metres of the old Grootfontein Eye site was $27.8 \mathrm{~m}$ bgl.

Of the 34 borehole water level records, all but two show a declining water level on average over the record length (Table 4). These two are both outside of the Grootfontein compartment (D4N0833 and D4N0830).

\section{Recharge}

Long-term recharge values of between $4.5 \%$ and $10 \%$ of annual rainfall have been estimated for Grootfontein (Cogho, 1982; Bredenkamp and van Rensburg, 1983; Dziembowski, 1995). However, in semi-arid North West Province recharge is a function of rainfall intensity, and may only occur in particularly wet years (Beekman and Xu, 2003; Van Wyk, 2010). Some authors (e.g. Janse van Rensburg, 1992) have incorporated this 'threshold effect' into their recharge calculations. Estimating recharge using conventional methods is complicated by its episodic nature, as well as by lack of data on rainfall chloride and stable isotope concentrations; lack of daily water level measurements and local rainfall data; and uncertainty regarding bypass flow and irrigation return flows.

A mass-balance approach to contemporary recharge is complicated by lack of knowledge of irrigation volumes and schedules, leakage across dykes, uncertainty over specific yield distribution, relatively coarse water-level data, and other factors. However, under pre-abstraction conditions, the natural recharge at Grootfontein would have been balanced by the long-term discharge of the Grootfontein Eye and other smaller springs (such as the Kleinfontein), plus evapotranspiration (ET) from vegetation and wetlands, plus any change in aquifer storage $(\Delta S)$. This basic mass balance can be expressed as follows:

Recharge $=$ Grootfontein flow + other spring flows $+\mathrm{ET} \pm \Delta \mathrm{S}$

If a long-term average situation is considered, then changes in aquifer storage can be ignored. Similarly, it is necessary to assume that flows across the boundaries of the aquifer, under natural conditions, are equalised in the long term. It follows that the sum of the long-term flows of the Grootfontein Eye and other springs would be a minimum figure for long-term recharge under natural conditions across the compartment. The evapotranspiration from wetlands that once existed would add to this figure, since they represented zones of groundwater discharge (they have now disappeared since the water table has dropped).

Unfortunately, detailed figures for the flow of the Grootfontein spring before borehole abstractions started are not available. Vipond (1979) reported that the average flow of the Grootfontein Eye at that time was $14.4 \mathrm{ML} /$ day $\left(5.3 \mathrm{Mm}^{3} / \mathrm{a}\right)$, thought to be close to the long-term average flow of the eye. One of the earliest technical reports to mention the Grootfontein Eye, by Temperley (1965 p 2), states:

A study of the records of Grootfontein shows that during the seven years since this spring was gauged, its yield has fallen from 1.5 to 0.75 thousand gallons per minute, a reduction of $50 \%$. This is attributed to a fall in the regional water level consequent on a steady increase in abstraction by boreholes for irrigation.

This implies that the gauging of the Grootfontein Eye began in the late 1950s. Assuming that Temperley (1965) meant imperial gallons, 1500 gallons per minute is about $9.8 \mathrm{ML} /$ day or $3.6 \mathrm{Mm}^{3} / \mathrm{a}$. Borehole abstractions had already started in the area in the 1950s, however, and were probably already affecting the flow of the Grootfontein Eye by the early 1960s. It seems likely, therefore, that the long-term flow of the Grootfontein Eye was at least $10 \mathrm{ML} /$ day $\left(3.7 \mathrm{Mm}^{3} / \mathrm{a}\right)$, and possibly as much as $20 \mathrm{ML} /$ day $\left(7.3 \mathrm{Mm}^{3} / \mathrm{a}\right)$. The flow of the Kleinfontein and other springs and seeps along the northern boundary of the aquifer also needs to be taken into account - likely at least another $10 \%$ of the Grootfontein flow, and possibly as much as a further $25 \%$ of its flow, based on discussions with local farmers. In summary, the long-term average of total spring discharges under pristine conditions from the Grootfontein aquifer was probably at least $11 \mathrm{ML} / \mathrm{day}\left(4.0 \mathrm{Mm}^{3} / \mathrm{a}\right)$, and possibly as much as $25 \mathrm{ML} /$ day $\left(9.1 \mathrm{Mm}^{3} / \mathrm{a}\right)$. 
TABLE 4

Water level summary at Grootfontein

\begin{tabular}{|c|c|c|c|c|c|c|c|c|}
\hline Borehole & Start date & Start wl & End date & End wl & Years & Trend & TrendGrad & AnnualDrop \\
\hline D4N0103 & $10-$ Feb-72 & 5.42 & 17-Feb-15 & 27.27 & 43.05 & decline & 0.002 & 0.56 \\
\hline D4N0037 & 10-Aug-73 & 20.62 & 23-Feb-12 & 28.85 & 38.56 & decline & 0.0018 & 0.21 \\
\hline D4N0051 & 5-Apr-74 & 17.1 & 23-Nov-09 & 32.76 & 35.66 & decline & 0.0016 & 0.42 \\
\hline D4N0080 & 8-Oct-74 & 6.99 & 23-Dec-08 & 26.9 & 34.23 & decline & 0.0023 & 0.59 \\
\hline D4N0088 & 8-Oct-74 & 11.37 & 18-Sep-07 & 36.8 & 32.97 & decline & 0.0023 & 0.81 \\
\hline D4N0092 & 15-Jan-75 & 29.22 & 24-Apr-13 & 36.67 & 38.30 & decline & 0.0009 & 0.28 \\
\hline D4N0094 & 15-Jan-75 & 21.24 & 15-Dec-04 & 33.21 & 29.94 & decline & 0.001 & 0.48 \\
\hline D4N0117 & 20-May-75 & 0.93 & 19-Feb-15 & 6.58 & 39.78 & decline & 0.0002 & 0.09 \\
\hline D4N0120 & 20-May-75 & 17.91 & 19-Feb-15 & 42.79 & 39.78 & decline & 0.0012 & 0.55 \\
\hline D4N0102 & 7-Jul-75 & 5.39 & 11-Nov-14 & 11.23 & 39.38 & decline & 0.0002 & 0.11 \\
\hline D4N0108 & 9-Jul-75 & 12.35 & 17-Feb-15 & 13.84 & 39.64 & decline & 0.0001 & 0.01 \\
\hline D4N0128 & 11-Aug-75 & 1.82 & 17-Feb-15 & 12.98 & 39.55 & decline & 0.001 & 0.28 \\
\hline D4N0095 & 15-Jan-76 & 28.33 & 19-Feb-15 & 38.01 & 39.12 & decline & 0.0009 & 0.17 \\
\hline D4N0111 & 15-Jan-76 & 15.7 & 10-Nov-09 & 30.75 & 33.84 & decline & 0.0016 & 0.53 \\
\hline D4N0039 & 10-Sep-76 & 3.39 & 17-Feb-15 & 14.3 & 38.46 & decline & 0.0005 & 0.26 \\
\hline D4N0113 & $15-$ Dec-76 & 5.8 & 17-Feb-15 & 22.87 & 38.20 & decline & 0.0008 & 0.37 \\
\hline D4N0129 & 20-Jan-77 & 8.94 & 22-Jun-10 & 8.96 & 33.44 & decline & 0.0001 & 0.07 \\
\hline D4N0075 & 30-Aug-79 & 3.6 & 17-Feb-15 & 27.91 & 35.49 & decline & 0.0021 & 0.67 \\
\hline D4N0852 & 4-Jun-81 & 11.34 & 11-Nov-14 & 28.09 & 33.46 & decline & 0.001 & 0.48 \\
\hline D4N0665 & 10-Nov-81 & 9.7 & 25-Jun-13 & 41.51 & 31.64 & decline & 0.0013 & 0.87 \\
\hline D4N0697 & 3-Jan-83 & 5.21 & 23-Feb-09 & 28.97 & 26.16 & decline & 0.0014 & 0.64 \\
\hline D4N0850 & 3-Jan-83 & 5.78 & 23-Feb-09 & 28.4 & 26.16 & decline & 0.0009 & 0.62 \\
\hline D4N0851 & 3-Jan-83 & 5.43 & 23-Feb-09 & 27.74 & 26.16 & decline & 0.0011 & 0.67 \\
\hline D4N0854 & 3-Jan-83 & 2.73 & 6-Jun-12 & 25.89 & 29.44 & decline & 0.0013 & 0.63 \\
\hline D4N0855 & 3-Jan-83 & 9.25 & 17-Feb-15 & 28.37 & 32.15 & decline & 0.0015 & 0.56 \\
\hline D4N0840 & 4-Oct-83 & 23.64 & 7-Dec-09 & 30.785 & 26.19 & decline & 0.0004 & 0.11 \\
\hline D4N0833 & $26-O c t-83$ & 8.5 & 15-Jul-04 & 8.85 & 20.73 & RISE & -0.0002 & -0.02 \\
\hline D4N0829 & 28-Oct-83 & 13.1 & 17-Feb-15 & 24.36 & 31.33 & decline & 0.0011 & 0.25 \\
\hline D4N0830 & 19-Jan-84 & 17.16 & 11-Nov-14 & 24.3 & 30.83 & RISE & -0.0003 & 0.02 \\
\hline D4N0838 & 15-Sep-86 & 28.05 & 7-Dec-09 & 31.82 & 23.24 & decline & 0.0002 & 0.01 \\
\hline D4N0839 & 15-Sep-86 & 28.88 & 7-Dec-09 & 32.65 & 23.24 & decline & 0.0003 & 0.11 \\
\hline D4N1664 & 31-Oct-97 & 28.83 & 3-Mar-15 & 47.6 & 17.35 & decline & 0.0034 & 1.26 \\
\hline D4N1668 & 10-Dec-98 & 33.06 & 19-Feb-15 & 37.81 & 16.21 & decline & 0.0012 & 0.22 \\
\hline C3N0653 & 9-Nov-10 & 28.31 & 18-Feb-15 & 32.46 & 4.28 & decline & 0.0033 & 0.80 \\
\hline
\end{tabular}

Start/End wl: First / last water level recorded for each record, in metres below datum.

Trend: $\quad$ Trend of best-fit straight line through each water level record.

TrendGrad: Gradient of best-fit straight line through each water level record.

Rise: $\quad$ Rising water level: Decline: Declining water level

AnnualDrop: Average annual change (drop) in water level over length of each record

Under natural conditions (i.e. before agriculture and human changes to the landscape), evapotranspiration by natural plant cover and evaporation from wetlands would have removed water from the aquifer, and these volumes would need to be added to the spring discharge volumes for a water balance. Today's evapotranspiration is partly a function of anthropogenic changes such as the modified plant cover or cropping patterns, the deeper water table, and soil moisture conditions in the soil zone due to irrigation. A reasonable assumption might be that natural evapotranspiration (i.e. not related to irrigation) is much reduced since the water table is considerably lower today, and no wetland areas remain.

There were two main areas of wetland within the compartment boundaries as shown on the old topographic maps: the course of the Droë Molopo River in the north-east, and a smaller area close to the farm Blaauwbank near the centre of the 
compartment (Fig. 2). Using GIS, their areas were estimated to be about $1.2 \mathrm{~km}^{2}$ and $0.22 \mathrm{~km}^{2}$, respectively. Assuming potential evaporation of $1500 \mathrm{~mm} / \mathrm{a}$ and standing water all year round, this implies that these areas together might have discharged as much as $5.8 \mathrm{ML} /$ day $\left(2.1 \mathrm{Mm}^{3} / \mathrm{a}\right)$ to evaporation.

This method uses 'pristine' conditions to derive a defensible upper and a lower limit to recharge. The minimum average recharge figure for the Grootfontein aquifer is probably about $13 \mathrm{ML} /$ day (about $4.7 \mathrm{Mm}^{3} / \mathrm{a}$ ), based on minimum spring discharges and low evapotranspiration, and corresponding to the minimum figures for percentage of rainfall quoted by previous authors. A maximum recharge figure of about $30 \mathrm{ML} /$ day (about $11 \mathrm{Mm}^{3} / \mathrm{a}$ ) would be based on maximum spring discharges combined with higher rates of evapotranspiration. The maximum figure quoted in the literature $(10 \%$ of mean annual rainfall, implying recharge of $36.5 \mathrm{ML} /$ day or 13.3 $\mathrm{Mm}^{3} / \mathrm{a}$ ) seems too high when considering likely discharges under 'pristine' conditions. Recharge figures corresponding to averages above $30 \mathrm{ML} /$ day $\left(11 \mathrm{Mm}^{3} / \mathrm{a}\right)$ may however be possible today due to the effects of induced recharge.

\section{Contemporary groundwater abstractions}

Current groundwater abstractions from the Grootfontein aquifer can be divided into three categories: the wellfield boreholes supplying Mahikeng, the irrigation boreholes spread across the aquifer, and miscellaneous other uses. Based on data obtained from DWS for 2015, the three remaining public water supply boreholes yield a combined average of $8.7 \mathrm{ML} /$ day (3.2 $\left.\mathrm{Mm}^{3} / \mathrm{a}\right)$. Estimating irrigation use is more difficult since licensed quantities are not enforced; however, work done for DWS by private consultants using satellite measurements of irrigated crop areas and knowledge of crop irritation requirements suggests that about $37 \mathrm{ML} /$ day $\left(13.5 \mathrm{Mm}^{3} / \mathrm{a}\right)$ is being abstracted for irrigation (Eales, 2015). Miscellaneous uses, including the public water supply boreholes in the southern part of the aquifer supplying Itsoseng, are estimated at about $3 \mathrm{ML} /$ day $\left(1.1 \mathrm{Mm}^{3} / \mathrm{a}\right)$. Combined average outflows are therefore roughly $49 \mathrm{ML} /$ day $\left(17.9 \mathrm{Mm}^{3} / \mathrm{a}\right)$.

\section{A water balance for the Grootfontein aquifer}

As described above, a recharge figure of between 13 and $30 \mathrm{ML} /$ day (4.7 and $11.0 \mathrm{Mm}^{3} / \mathrm{a}$ ) was estimated. (This corresponds to roughly $3 \%$ to $8 \%$ of average annual rainfall across the aquifer area, respectively.) If zero flux across the aquifer boundaries is assumed, then: Inflows - Outflows $\pm \Delta S=0$, and a contemporary water balance can be constructed for Grootfontein (Table 5).

\section{DISCUSSION AND CONCLUSIONS}

Grootfontein currently has a groundwater deficit of at least $(49-30=) 19 \mathrm{ML} /$ day $\left(6.9 \mathrm{Mm}^{3} / \mathrm{a}\right)$, and as much as (49-13 =) $36 \mathrm{ML} /$ day $\left(13.1 \mathrm{Mm}^{3} / \mathrm{a}\right)$, based on estimates of current inflows and outflows. Alternatively, long-term water-level declines averaging $0.4 \mathrm{~m} / \mathrm{a}$ suggest a long-term average deficit of between about 5 and $26 \mathrm{ML} /$ day (1.8 and 9.5 $\mathrm{Mm}^{3} / \mathrm{a}$ ), based on minimum and maximum estimates of aquifer specific yield. The discrepancy between long-term estimates based on water-level changes, and estimates based on current irrigation abstractions, is partly due to increasing irrigation. Recent sampling confirms that the groundwater quality is good.

Although hydrogeological uncertainty is inevitable, it is clear that the Grootfontein aquifer is being over-exploited. Abstractions must fall if water levels are to recover. Remaining uncertainty should not defer better governance - indeed, uncertainty will diminish as improved governance and monitoring refine the conceptual model (Seward et al., 2006; Cobbing, 2017). Calls to restrict abstractions at Grootfontein have been regularly made in the hydrogeological literature since the 1960s, mainly by DWS hydrogeologists (e.g. Bredenkamp, 1964). South African water law and policy also

\begin{tabular}{|c|c|c|}
\hline \multicolumn{3}{|c|}{$\begin{array}{c}\text { TABLE } 5 \\
\text { Grootfontein water balance }\end{array}$} \\
\hline Inflows & Estimate & Notes \\
\hline Recharge & $\begin{array}{l}\text { Between } 13 \mathrm{ML} / \text { day and } 30 \mathrm{ML} / \\
\text { day }(4.7 \text { and } 11.0 \mathrm{Mm} 3 / \mathrm{a})\end{array}$ & $\begin{array}{l}\text { Based on spring discharges and estimated } \\
\text { evapotranspiration under pre-abstraction conditions }\end{array}$ \\
\hline Return flows & $\begin{array}{l}\text { Assumed to be zero under } \\
\text { current conditions }\end{array}$ & May be a locally significant source of recharge \\
\hline $\begin{array}{l}\text { Inflows across aquifer } \\
\text { boundaries }\end{array}$ & $\begin{array}{l}\text { Assumed to be zero under } \\
\text { current conditions }\end{array}$ & $\begin{array}{l}\text { May be significant particularly where water levels have } \\
\text { dropped and/or dykes are highly weathered }\end{array}$ \\
\hline \multicolumn{3}{|l|}{ Outflows } \\
\hline Irrigation boreholes & $\begin{array}{l}37 \text { ML/day (13.5 Mm3/a), may be } \\
\text { higher }\end{array}$ & $\begin{array}{l}\text { Estimated using satellite data (DWS' WARMS licence data } \\
\text { implies amount is higher) }\end{array}$ \\
\hline Evapotranspiration & $\begin{array}{l}\text { Assumed to be zero under } \\
\text { current conditions }\end{array}$ & $\begin{array}{l}\text { Falling water tables have eradicated wetland areas, springs } \\
\text { and seeps }\end{array}$ \\
\hline DWS boreholes & 8.7 ML/day (3.2 Mm3/a) & $\begin{array}{l}\text { Based on DWS } 2015 \text { data, was higher up until about } 2010 \\
\text { (DWS, 2014) }\end{array}$ \\
\hline Other boreholes & About 3.0 ML/day (1.1 Mm3/a) & $\begin{array}{l}\text { Mainly Itsoseng boreholes for public supply, since other } \\
\text { abstractions are small }\end{array}$ \\
\hline \multicolumn{3}{|l|}{$\Delta$ Storage } \\
\hline Falling groundwater levels & $\begin{array}{l}\text { Between } 5.2 \mathrm{ML} / \text { day and } 26 \mathrm{ML} / \\
\text { day (1.9 and } 9.5 \mathrm{Mm} 3 / \mathrm{a})\end{array}$ & $\begin{array}{l}\text { Figure based on specific yields of } 2 \%(\mathrm{~min}) \text { and } 10 \%(\max ) \\
\text { and average drop in water levels of } 0.4 \mathrm{~m} / \mathrm{a} \text { across the aquifer }\end{array}$ \\
\hline
\end{tabular}


specify sustainable use, and protection of ecosystems. Yet overabstraction at Grootfontein continues, with all of the implied risks and costs.

It is sometimes thought or implied that poor knowledge of groundwater resources in South Africa is behind a collective failure to fully utilize this resource, or behind a preference for surface water alternatives (DWA, 2010). However, current hydrogeological understanding of Grootfontein enables a defensible water balance to be constructed from publicly available data as demonstrated above, suggesting that lack of technical knowledge of the aquifer cannot be blamed for poor management. It follows that more hydrogeological work, on its own, will not automatically lead to better management of groundwater - indeed, may even reinforce the regressive notion that the solution to groundwater management lies mainly in further technical work. This would only continue the 50 -year tradition of detailed hydrogeological studies being done whilst water levels fell, and the poor coordination between hydrogeological work and management practice. A full discussion of the interaction between the hydrological and social spheres is beyond the scope of this article, but has been discussed elsewhere (e.g. Cobbing, 2017).

The failure to better utilise groundwater in the public interest is not limited to Grootfontein, but appears to be more widespread. In Cape Town, for example, planners are installing desalination plants, whilst at the same time grappling with seasonal flooding and sanitation problems on the Cape Flats - problems that would partly be addressed by pumping this groundwater. Various proposals over the years to use the water (and storage potential) of the well-studied Cape Flats Aquifer (e.g. Maclear, 1995; Wright and Conrad, 1995) have not been adopted. Plans to incorporate the good quality groundwater in the Cape Fold Mountains into Cape Town's supply have also fared poorly. Innovative proposals to use aquifer storage to buffer seasonal demand at Plettenburg Bay and Sedgefield were trumped by costly surface water and desalination options, respectively.

A more holistic view of South Africa's groundwater as a national resource is required, taking into account the wider management, funding, legal, policy, and operational context as well as the hydrogeological realities. Mahikeng is already paying a high price for essentially abandoning the Grootfontein aquifer, since expensively treated dam water must substitute for the decline of Grootfontein. This price will rise further since other sources of water in this semi-arid area are scarce and expensive. Concerns over water in Mahikeng also influence the wider social and economic context, with difficult-to-quantify implications for employment, equity, stability and economic development.

\section{ACKNOWLEDGEMENTS}

This research forms part of trans-disciplinary work done towards a PhD at Nelson Mandela University's Africa Earth Observatory Network / Earth Stewardship Science Research Institute (AEON/ESSRI) in the field of Earth Stewardship Science (De Wit and Booth, 2016). This It also formed part of two Water Research Commission projects (K5/2158 and $\mathrm{K} 5 / 2429$ ). The author is grateful for the supervision and guidance of Professor Maarten de Wit, and staff and students at AEON/ESSRI, Nelson Mandela University. This is AEON/ ESSRI Publication No. 167. The Water Research Commission in Pretoria supported and encouraged this work, and provided a forum for useful discussions. The author would also like to thank the anonymous reviewers of this manuscript.

\section{REFERENCES}

BARNARD HC (2000) An Explanation of the 1:500 000 General Hydrogeological Map Johannesburg 2526. Department of Water Affairs and Forestry, Pretoria.

BEEKMAN, HE and XU Y (2003) Review of groundwater recharge estimation in arid and semi-arid Southern Africa. In: Xu Y and Beekman HE (eds.) Groundwater Recharge Estimation in Southern Africa. UNESCO IHP Series No. 64. 3-18.

BREDENKAMP DB (1964) Verslag van hidrologiese opname in die Bo-Molopo Ondergrondse Waterbeheergebied. Report No. GH 1283, Department of Water and Sanitation, Pretoria.

BREDENKAMP DB and VAN RENSBURG JH (1983) Ondersoek na die lewering van die Grootfontein en Polfonteinkompartemente aan die hand van 'n eindige verskil model. Report No. GH 3291. Department of Water and Sanitation, Pretoria.

CGS (Council for Geoscience) (1981) 1:250 000 Geological Map Sheet 2526 Rustenburg. Council for Geoscience, Pretoria.

CGS (Council for Geoscience) (1986) 1:250 000 Geological Map Sheet 2626 Wes-Rand. Council for Geoscience, Pretoria.

CGS (Council for Geoscience) (1991) 1:250 000 Geological Map Sheet 2524 Mafikeng. Council for Geoscience, Pretoria.

CGS (Council for Geoscience) (1993) 1:250 000 Geological Map Sheet 2624 Vryburg. Council for Geoscience, Pretoria.

CGS (Council for Geoscience) (1997) 1:1 000000 Geological Map of South Africa. Council for Geoscience, Pretoria.

COBBING JE (2017) The Grootfontein aquifer as a hydro-social system. Unpublished dissertation submitted in the fulfillment of the requirements for the degree of Doctor of Philosophy in the Faculty of Science, Nelson Mandela Metropolitan University, Port Elizabeth.

COGHO VE (1982) Die ontginbare grondwaterpotensiaal van die Grootfonteinkompartement. Report No. GH 3242, Department of Water and Sanitation, Pretoria.

COGHO VE and BREDENKAMP DB (1982) Grondwaterpotensiaal van die Grootfontein Kompartement volgens n wiskundige model. Paper presented at Groundwater 82 conference, Ground Water Division of the Geological Society of South Africa, Johannesburg.

DAY RW (1981) A Magnetometric Investigation of the LichtenburgZeerust Area. Bulletin 68. Department of Mineral and Energy Affairs. Government Printers, Pretoria.

DE WIT MJ and BOOTH P (2016) Iphakade is Earth Stewardship Science. S. Afr. J. Geol. 119 (1) 3-14. https://doi.org/10.2113/ gssajg.119.1.3

DWA (Department of Water Affairs, South Africa) (2006) Vaal River System Large Bulk Water Supply Reconciliation Strategy. Groundwater Assessment: Dolomite aquifers. DWAF Report No. P RSA C000/00/4406/06. Prepared by DMM Development Consultants, Golder Associates Africa, SRK, WRP Consulting Engineers and Zitholele Consulting for the Department of Water Affairs and Forestry, December 2006, Pretoria. URL: https:// www.dwa.gov.za/projects/vaal/documents/LargeBulkWater/06_ Dolomitic\%20Groundwater\%20Assessment_Final.pdf (Accessed January 2017).

DWA (Department of Water Affairs, South Africa) (2010) Groundwater Strategy 2010. Department of Water Affairs, Pretoria.

DWS (Department of Water and Sanitation, South Africa) (2014) Third Quarter Performance Evaluation Report for Greater Mafikeng Bulk Water Supply Scheme. Period 1 October to 31 December 2014. Chief Directorate: Bulk Infrastructure Programme, Department of Water and Sanitation, Pretoria.

DZIEMBOWSKI ZM (1995) Grondwatertoestande in die Bo-Molopo Ondergrondse Staatswaterbeheergebied in 1995. Report No. GH 3869. Department of Water and Sanitation, Pretoria.

EALES K (2015) Report on economic aspects: the path to successful water user associations in the North West dolomites. Deliverable 3 of WRC Project K5/2429. Water Research Commission, Pretoria.

HOLLAND M and WIEGMANS F (2009) Geohydrology Guideline Development: Activity 18\&19 Desktop development of a dolomite hydrogeological compartment map and explanation booklet (Report). Report prepared for the Department of Water Affairs by Water Geosciences Consulting as part of DWA Project Number: 14/14/5/2 Implementation of Dolomite Guideline. Department of Water Affairs, Pretoria. 
JANSE VAN RENSBURG H (1992) Re-evaluation of the exploitation potential of the Grootfontein compartment (Western Transvaal). Report No. GH 3788. Department of Water Affairs and Forestry, Pretoria.

JOHNSON MR, ANHAEUSSER CR and THOMAS RJ (eds) (2006) The Geology of South Africa. The Geological Society of South Africa and the South African Council for Geoscience, Johannesburg.

MACLEAR LGA (1995) Cape Town needs groundwater. A note on the potential of the Cape Flats aquifer unit to supply groundwater for domestic Use in the Cape Town Metropolitan Area. Technical Report No. Gh3868. Department of Water and Sanitation, Cape Town. URL: http://www.wellcore.co.za/ downloads/CapeTownNeedsGroundwater.pdf (Accessed January 2017).

MDH (Minnesota Department of Health, USA) (1999) Screening Evaluation of Arsenic, Cadmium, and Lead Levels in Minnesota Fertilizer Products. Minnesota Department of Health, Minnesota, USA. URL: http://www.health.state.mn.us/divs/eh/risk/studies/ fertrpt.pdf (Accessed January 2017).

MEYER R (2012) Hydrogeology of Groundwater Region 10: The Karst Belt. Water Research Commission Report No. TT 553/12. Water Research Commission, Pretoria.

MULDER MP (1982) Opsomming van resultate verkry vir in voorlopige raming van die grondwaterpotensiaal van die Grootfontein staatswaterwerke. Report No. GH 3220. Department of Water and Sanitation, Pretoria.

SANS 241-1 (2011) South African National Standard: Drinking Water. Part 1: Microbiological, physical, aesthetic and chemical determinands. SABS Standards Division, Pretoria.
SANS 241-2 (2011) South African National Standard: Drinking Water. Part 2: Application of SANS 241-1. SABS Standards Division, Pretoria.

SEWARD P, XU Y and BRENDONCK L (2006) Sustainable groundwater use, the capture principle, and adaptive management. Water SA 32 (4) 473-482.

STEPHENS A and BREDENKAMP DB (2002) Institutional arrangements for groundwater management in dolomitic terrains: situation analysis. WRC Report No. KV140/02. Water Research Commission, Pretoria.

TEMPERLEY BN (1965) Groundwater conditions on Spring Valley Farm, Rooigrond near Mafikeng. Report No. GH 1273. Department of Water and Sanitation, Pretoria.

TINKER J, DE WIT M and GROTZINGER J (2002) Seismic stratigraphic constraints on neoarchean-paleoproterozoic evolution of the western margin of the Kaapvaal Craton, South Africa. S. Afr. J. Geol. 105 107-134. https://doi.org/10.2113/105.2.107

VAN TONDER GH, JANSE VAN RENSBURG H, BOTHA JF and BREDENKAMP DB (1986) Die modellering van grondwatervlakke in die Grootfonteinkompartement in Wes-Transvaal. Water SA 12 (3) $151-160$.

VAN WYK E (2010) Estimation of episodic groundwater recharge in semi-arid fractured hard-rock aquifers. PhD thesis, University of the Free State, Bloemfontein.

VIPOND SH (1979) Increased groundwater abstraction at Grootfontein - water supply to Mafikeng and Mmabatho. Report No. GH 3091, Department of Water and Sanitation, Pretoria.

WRIGHT A and CONRAD J (1995) The Cape Flats Aquifer current status. CSIR Environmentek Report No. 11/95. CSIR, Stellenbosch. 